\begin{tabular}{|c|c|c|c|c|c|c|}
\hline \multirow{4}{*}{ Impact Factor: } & ISRA (India) & $=3.117$ & SIS (USA) & $=0.912$ & ICV (Poland) & $=6.630$ \\
\hline & ISI (Dubai, UAE & $=0.829$ & РИНЦ (Russia) & $=0.156$ & PIF (India) & $=1.940$ \\
\hline & GIF (Australia) & $=0.564$ & ESJI (KZ) & $=8.716$ & IBI (India) & $=4.260$ \\
\hline & JIF & $=1.500$ & SJIF (Morocco) & $=5.667$ & OAJI (USA) & $=0.350$ \\
\hline
\end{tabular}

\section{SOI: 1.1/TAS DOI: 10.15863/TAS International Scientific Journal Theoretical \& Applied Science}

p-ISSN: 2308-4944 (print) e-ISSN: 2409-0085 (online)

Year: 2019 Issue: $05 \quad$ Volume: 73

Published: $30.05 .2019 \quad$ http://T-Science.org

SECTION 17. World history. History of science and technology.
QR - Issue
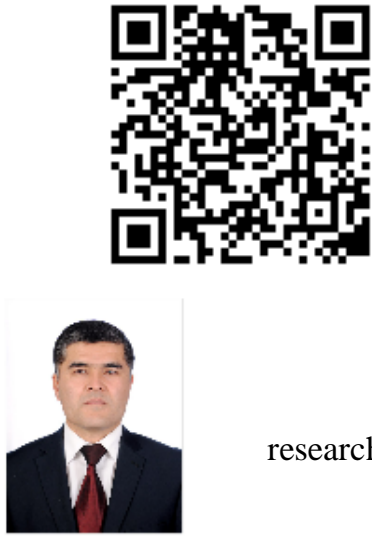

QR - Article

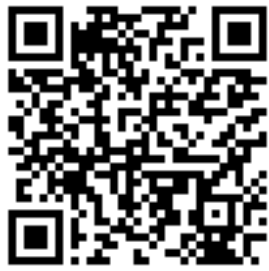

Davronbek Makhsudov

Associate professor, Doctor of philosophy (PhD) researcher of the International Islamic

Academy of Uzbekistan

\title{
A GENIUS OF THE WORLD
}

Abstract: The article tells about the life and the work of Abu-l-Barakat an-Nasafi, who was one of the prominent and distinguished medieval scholar in the field of Islamic sciences in Central Asia and his contribution to Islamic sciences. The article also analyzes the works of Abu-l-Barakat an-Nasafi in the field of Islamic law and tafsir. The article gives a general idea that Abu-l-Barakat an-Nasafi is the scientist, who made a tremendous contribution to the formation and further development of the religious and secular sciences, especially to the dissemination of the Hanafian order and teachings of the Maturidia School in the Islamic world and left a great amount of scientific heritage. For his contribution to Islamic sciences he was given an honorable title of "A Genious of the world".

Key words: tafsir, mufassir (commentator of the Quran), nahv (syntax), hadith, imam, usulu ilm, Maturidia School, Nasaf, Abu-l-Barakat, Hafiz ad-din.

Language: English

Citation: Makhsudov, D. (2019). A genius of the world. ISJ Theoretical \& Applied Science, 05 (73), 544-548. Soi: http://s-o-i.org/1.1/TAS-05-73-84 Doi: crossef https://dx.doi.org/10.15863/TAS.2019.05.73.84

\section{INTRODUCTION}

The full name of the genius who lived in the 8th century was Hafiz ad-din Abu-1-Barakat Abdullah ibn Ahmad ibn Majmud an-Nasafi. In the book "AlMavsua al-arabiya al-muyassare by Muhammad Shafiq Girbal, his birth date is shown to be 1232 [1: 1833]. He successfully worked in different branches of Islamic studies such as tafsir, law and kalam and left us precious books that have been appreciated by the experts as a valuable and rare source in the abovementioned branches of science and have been studied attentively by the researchers. He died in 710/1310 in Baghdad on a Friday evening of the month Rabi alavval. He was buried in the city of Hijaz situated between Huzistan and Isfahan [2: 22].

In the process of his becoming a highly estimated and appreciated scholar of his time, much was done by his teachers and tutors. One of such respectable teachers of Abu-1-Barakat an-Nasafi was well-known scholar of his time Abu-I-Vajd Shams al-Am Muhammad al-Kardari. He taught the promising scholar subjects as tafsir, law and kalam. In his turn, Abu-l-Vajd Shams al-Aimma Muhammad al-Kardari had been taught by the the author of the book "Hidaya" Burhan ad-din al-Marginani and the author of the book "Fatava Qazikhan" Fakhr ad-din Qazikhan, etc. [3: 290-291]
According to the information at our disposal, one of the first who had spread the science of law was Abu Zayd ad Dabusi [3: 291]. After him, Abu-l-Vajd Shams al-Aimma Muhammad al Kardari was recognized in the science as the person who had reanimated this subject as a science. Perhaps, because of this act, hundreds of lawyers were educated in Maveraunnahr.

Abu-l-Barakat an-Nasafi had some more teachers and masters such as Hamid ad-din az-Zarir Ali ibn Muhammad Ali ar-Ramishi and Badr ad-din Khavahirzada Muhammad ibn Mahmud ibn Abdulkarim [3: 290-291]. Having absorbed the knowledge and science from such well-known teachers and masters, Abu-l-Barakat received the honored title of "Hafiz ad-din" (defender of the religion). There were two nominees to that honorable title at that time. The second one was a scholar Hafiz ad-din Abu-l-Fadl Muhammad ibn Muhammad ibn Nasr al-Kabir al-Bukhari. Both of these scholars were taught by a genius master ar-Kardari [4: 312].

\section{MATERIALS AND METHODS}

Abu-l-Barakat an-Nasafi is the author of many books. For instance, "Kanz ad-daqaiq" (A Treasure of Delicate Questions), "Al-Vafi" (Full) and its commentaries "Al-Kafi" Satisfactory). The experts 


\begin{tabular}{|c|c|c|c|c|c|c|}
\hline \multirow{4}{*}{ Impact Factor: } & ISRA (India) & $=3.117$ & SIS (USA) & $=0.912$ & ICV (Poland) & $=6.630$ \\
\hline & ISI (Dubai, UAI & $=0.829$ & РИНЦ (Russia & $=0.156$ & PIF (India) & $=1.940$ \\
\hline & GIF (Australia) & $=0.564$ & ESJI (KZ) & $=8.716$ & IBI (India) & $=4.260$ \\
\hline & JIF & $=1.500$ & SJIF (Morocco & $=5.667$ & OAJI (USA) & $=0.350$ \\
\hline
\end{tabular}

consider that his book "Kanz ad-daqiq is the second best book in the field of law after "Hidaya by Burhan ad-din al-Marghinani.

The urgent problems of the Islamic law such as prayer, fasting, haj, punishment as well as the ideas promoted by different scholars as Abu Hanifa, Abu Yusuf, Imam Muhammad, Imom Zufar and Imam ashShafi'i on these matters and Hadiths are mentioned in "Kanz ad-daqaiq". The book was translated into Persian by Nasrullah ibn Muhammad al-Kermani. The Urdu version of the book was prepared by Ahlullah ibn Sheikh Abdurahim. Moreover, the manuscript of the book has several times been copied and published by different publishers.

As a precious and rare original source "Kanz addaqaiq" was commented on by different authors. Imam Fakhruddin Usman ibn Ali az-Zaylai's "Tabyin al-haqaiq lima fihi ma intaza'a min ad- daqaiq" (Description of reality of problems taken from "Addaqaiq"), Zayn al-Abidin ibn Najm al-Misri's (died in 970/1562 1563) "Al-Bahr ar-raiq fi sharh Kanz ad-daqaiq (Transparent sea of commentaries of "Kanz ad-daqaiq") are some of the most famous samples of them.

Another most precious and appreciated source written by Abu-1-Barakat in the field of law is his book "Al-Vafi" (Full). This book is so invaluable that most experts put it alongside with "Hidaya" by Burhan addin al-Marghinani. Such an approach to this book may be found in Katib Chelebi's book "Kashf az-zunun" (Settlement of Hesitations). According to the opinion put forward by Katib Chelebi, Abu-l-Barakat anNasafi decided to write commentaries on "Hidaya" by Burhan ad-din al-Marghinani but one of the leading specialists in law of that time Taj ash-Shariah persuaded him not to do so. Then Abu-1-Barakat anNasafi attempted to write his book on law "Al-Vafi" and its commentary "Al-Kafi". With this, he satisfied himself as if he had commented on "Hidaya". This work has incomparable authority among books written on the Islamic law [5: 1115-1117].

Abu-l-Barakat an-Nasafi's next book "AlManar" (Light) was written to describe the main principles of the Islamic law, legal matters, their rules and claims. It also describes such legal matters of Islam based on the Holy Qur'an and Hadiths as types of punishment (sentence, ijma and qias) and the cases and ways of using them. [6: 6-7] This manual is appreciated by the experts of law as a short and laconic answer to most of the controversial problems of the Islamic law. Therefore, this subject based on the commentaries of experts is taught in our religious educational institutions. Barakat an-Nasafi began his book "Al-Manar" with "praising the Creator and classified the main principles of Shariah haria) into four main component parts as the Qur'an, Sunnah, ijma and qias (comparison). He stressed that the rest of matters are decided on the basis of those abovementioned principles of Shariah.
As the original sources witness us, the first person to compile the principles of Shariah the form of a book was the founder of the Shafi'i order Imam Ash-Shafi'i. $\mathrm{He}$ was followed by some representatives of other orders in religion. "AlManar" by Abul Barakat an-Nasafi is one of them to which some commentaries were devoted by the leading specialists of that time. An-Nasafi himself commented on his own book and titled it as "Kashf alAsrar" (Disclosing the Secrets). One of his followers Kafi al-Aghisari made a commentary on the work under discussion in the form of a small booklet [5: 519]. The list of such commentaries may be continued by the following works:

- "Nur al-anvar fi sharh al-Manar" (A light ray of commentaries of al-Manar) by Ahmad ibn Abu Said al-Hanafi;

- "Ifada al-anvar fi izai usul al-Manar" (The use of rays in the spread of styles of al-Manar) by Sa'd addin Abu-1-Fadail adDehlavi (died in 1486-87);

"Tabassurat al-Asrar fi sharh al-Manar" (The ability of seeing the secrets of commentaries of alManar) by Sheikh Shija adin Hibatullah ibn Ahmad at-Turkistani (died in 1332-33);

"Jami al-Asrar" (A collector of secrets) by Qivam ad-din Muhammad ibn Muhammad atTurkistani (died in 1348-49), etc.

Besides those above-mentioned works, there are some more books belonging to the pen of Abu-lBarakat an-Nasafi. They are as follows:

1. "Al-Musaffali commentary on Al-Musaffa fi sharh al-manzuma an-Nasafiya (Defined ry on the poetry of an-Nasafi) - belonging to the science of kalam;

2. "Al-Mustasfa fi sharh al-fiqh an-nafi" (Selected useful commentaries) - belonging to the science of law;

3. "Umdat al-aqaid" (The basis of teachings) belonging the science of kalam [7: 41-47].

A number of works belonging to the pen of Abu1-Barakat Nasafi are preserved in the scientific library of the Institute of Oriental Studies named after Abu Rayhan Beruni of the Academy of Sciences of the Republic of Uzbekistan

"Umdat al-aqaid" by Hafiz ad-din an-Nasafi is a book that covers most of the urgent and controversial problems of the science of kalam. Dozens of commentaries were devoted to this book by the leading experts of his time. Among them we can mention some which are:

1. "Az-Zubda" (Cream) by Jamal ad-din Mahmud ibn Ahmad al-Kavnavi (died in 770/136869):

2. Al-Inqad" (Rescue) by a scholar who lived in the 14th century Amad al-Aqshahari al-Hanafi.

It is worthy to call his next book titled "Madarik at-tanzil va haqaiq at-ta vil" (Meanings of the Holy Qur'an and realities of ta'vil) as the best one in the field of tafsir. It is also known as "Tafsir an-Nasafi". 


\begin{tabular}{|c|c|c|c|c|c|c|}
\hline \multirow{4}{*}{ Impact Factor: } & ISRA (India) & $=3.117$ & SIS (USA) & $=0.912$ & ICV (Poland) & $=6.630$ \\
\hline & ISI (Dubai, UAI & $=0.829$ & РИНЦ (Russia & $=0.156$ & PIF (India) & $=1.940$ \\
\hline & GIF (Australia) & $=0.564$ & ESJI (KZ) & $=8.716$ & IBI (India) & $=4.260$ \\
\hline & JIF & $=1.500$ & SJIF (Morocco & $=5.667$ & OAJI (USA) & $=0.350$ \\
\hline
\end{tabular}

Among the books devoted to the science of Tafsir "Tafsir an-Nasafi" is the most precious and appreciated one by Abu-1-Barakat an-Nasafi because it covers the most urgent problems of the science of tafsir which was written under the spirit of the teachings of the Hanafian order. The meanings of ayahs of the Holy Qur'an are commented under the visions of Imam Abu Mansur Maturidi and his Maturidiya School. These views are enriched with the ideas promoted by the outstanding specialists Samarkand and Bukhara. A number of utterances and ideas Imam Maturidi and his book "Ta'vilat ahl asSunnah" are cited this tafsir. Alongside with them, in the commentaries of ayahs the author thor often uses the phrase "indana" meaning 'in our view, in our opinion' or 'in our order' [8: 778.]

One of the important peculiarities of the tafsir is in the fact that philological features of the ayahs and their analysis are carried out in detail and with a great mastership. The full essence of Qur'an and its main ideas are revealed masterfully. To reach this purpose the author had to cite and comment on the ideas promoted by the estimated scholars of his time as Imam Sibavayah and Imam Farra. In order that the reader of the Qur'an could fully understand the meaning of ayahs, an-Nasafi provided seven types of approaches principles of reading ayahs. It is perhaps because of this that this book is often addressed by the readers of Qur'an. While translating the Holy Qur'an into Uzbek, the translator Abdulaziz Mansur also used this book effectively [9].

The Arabic word "tafsir" is defined in dictionaries as a word maning (pl. tafasir) "defining, clarifying, making clear, expressing, declaring", etc. The scholars define the nature of this term differently and use it to denote different meanings. According to their vision, tafsir" is used to denote "a science which expresses and describes the essence of the words of Allah" or "a science which reveals the meanings of the words and phrases used in the Holy Qur'an" or science which studies the purposes and aims of Allah expressed in the ayahs of the Holy Qur'an from the point of view of Man" [7: 48-55].

Tafsirs played the most important role in understanding the ideas of the Holy Qur'an. In order to make the believers follow their ideas and teachings, different separated parties and groups in religion made many efforts to use tafsirs as a weapon in their fights leadership in religion. In order to reach their aggressive purposes, they even tried to explain the essence of ayahs erroneously and with bias. They even did not stop before the incorrect explanation of tafsirs. Especially, in the fights of the Abbasids for the power of the Caliphate, incorrect and wrong descriptions and explanations of tafsirs were widely used as a main weapon by the Abbasids.

In the course of time lots of tafsirs were created by the scholars and it is perhaps, firstly, because of the attempts to explain essence of ayahs for the ordinary people and, secondly, the growth the number of tafsirs was dictated by the development of science Alongside with the religious sciences, such branches of sciences of the secular world as philosophy, grammar, syntax and the like were greatly influenced by the essence of tafsirs [10: 31, 66].

As the scholars of Maveraunnahr were the supporters of the teachings and ideas of the Hanafian order, the tafsirs written by them fully met the requirements of this order. Among such tafsirs we can mention as most important ones the following works:

1. "Ta'vilat as-Sunnah" by Abu Mansur alMaturidi;

2. "At-Tafsir" by Abu Is'ha Ibrahim ibn Ma'qil an-Nasafi (died in 907-908);

3. "Tafsir al-Qur'an al-karim" by Abu Lays Nasr ibn Muhammad ibn Amad as-Samarqandi (died in 1002-03);

4. "At-Tafsir" by Hujjat al-Afadil Ali ibn Muhammad alKhoresmi (died in 1164-1165);

5. "Fazail al-Qur'an" (Peculiarities of the Qur'an) by Abu-lAbbas Ja'far ibn Muhammad al-Mustaghfiri an-Nasafi (died in 1041)

Alongside with those above-mentioned scholars, the list of authors who were engaged in compiling tafsirs and commenting on them may be continued with the following names:

1. Abu Riza Muhammad ibn Ali an-Nasafi (died in 1123-24):

2. Abu-l-Fadail Muhammad al-Hanafi Burhan an-Nasafi (died in 1287-88);

3. Abu Sa'd Muhammad ibn Muhammad alAmadi (died in 1574-75)

"Madarik at-tanzil va haqaiq at-tavil" by Abu-1Barakat Nasafi is used as a manual on the subject of tafsir at the relig educational centres of the Islamic world alongside with such known textbooks and manuals as "Tafsir al-Bayzavi", "Tafsir al-Jalalayn" and "Tafsir ibn Kasir". Among these manuals "Tafsir an-Nasafi" meets requirements and supports the ideas and teachings of the Hanafian order at are the tafsirs of the Shafi'ia order. Therefore, those students who wish to learn the essence of ayahs of the Holy Qur'an from the points of view of the Hanafian order should refer to the "Tafsir an- Nasafi". The last version of the book was published in Beirut in 1999 by the "Dar ibn Kasir" publishing house.

In the preface of his book, Abu-l-Barakat anNasafi wrote the following lines: "I was asked by my colleagues and close friends to write a book in a laconic and understandable style that could explain the essence of the ayahs of the Holy Qur'an mentioning different approaches to the rules of reading the Qur'an and showing all the acts and attitudes to the principles of reading Qur'an in accord with the claims of "ahli Sunnah va-1-jamaa". At the beginning. I hesitated but at last, thanks to the mercifulness and support of Allah, I had the courage to write the book and soon I finished it. I titled my book as "Madarik at-tanzil va 


\begin{tabular}{|c|c|c|c|c|c|c|}
\hline \multirow{4}{*}{ Impact Factor: } & ISRA (India) & $=3.117$ & SIS (USA) & $=0.912$ & ICV (Poland) & $=6.630$ \\
\hline & ISI (Dubai, UAI & $=0.829$ & РИНЦ (Russia & $=0.156$ & PIF (India) & $=1.940$ \\
\hline & GIF (Australia) & $=0.564$ & ESJI (KZ) & $=8.716$ & IBI (India) & $=4.260$ \\
\hline & JIF & $=1.500$ & SJIF (Morocco & $=5.667$ & OAJI (USA) & $=0.350$ \\
\hline
\end{tabular}

haqaiq at-ta'vil". Allah is able to make things easy and the most powerful Creator who can do anything he wishes and is able to realize our wishes in prayers".

As is mentioned by an Arabic scholar Muhammad az-Zahabi in his book "At-Tafsir va-lmufassirun" the style of writing of "Tafsir an-Nasafi" resembles the style of "Anvar at-tanzil va asror at la vil" (Rays of the Qur'an and the secrets of ta' vil) by Qazi alBayzavi and "Al-Kashshaf" (Discoverer) by a scholar Mahmud az-Zamakhshari, our countryman from Khoresm. However, al-Bayzavi represents the Shafi'i order and az-Zamakhshari supports the teaching of the Mu'tazilah trend in Islam. Therefore, there are lots of differences in the approaches to the claims of those orders and in principles of explanations of the meaning of ayahs of the Holy Qur'an.

In the most parts of his explanations of tafsirs Abu-1-Barakat an Nasafi relies on the legends and ideas expressed by ibn Abbas, an experienced expert in tafsirs, the supporter and followerof the teachings of Prophet Muhammad (saas). Further, he uses the legends mentioned by Sahabas and Tabi'iys as Ibn Mas' ibn Malik, Hasan, Ubay ibn Ka'b Mujahid, etc. For instance, the word "pray" in the ayah of the Qur'an "Pray to your Creator" (Baqara, 21) is commented by Ibn Abbas in the following "Each prayer in the Qur'an means the uniqueness of Allah"

Anas ibn Malik says: "Anyone who read the "Baqara" and Imran" Surahs would be the greatest of us".

One who reads "Tafsir an-Nasafi" can see that the ideas of the book are based logically and scientifically, good will and knowledge is appreciated but evil and wrongdoings are criticized mercilessly.

The ayahs of the Qur'an saying, "Oh, my God make my knowledge richer" and "Are the owners of good knowledge equal to those who lack them are samples of those ayahs.

Commenting on the ayahs dealing with science and knowledge An-Nasafi writes the following: "The knowledge, even if it is owned by the priest, may lead to the right way of behavior. Because this ayah says, "You can see that those people who say, "We are Christians" may be closer to us, the Muslims. Because they have priests among them and they are not very keen on pride and self-conceitedness."

By this fact an-Nasafi wants to prove that no matter who may acquire the knowledge, it is great and preferable, and it even caused the knowledgeable Christians to be mentioned in the Qur'an positively.

Alongside with commenting on ayahs of the Qur'an, an-Nasali gave reasonable refusals to the claims of those separated parties groups who went astray in the process of understanding the essence of the ayahs. For instance, the author tries to prove that the paradise was created by Allah and it exists even today. Because having created Adam and Eve, God said, "You and your live in the paradise". Thus, the scholar stresses the existence of paradise at that time and today and provides proofs again ideas of Mu'tazilis.

Moreover, Abu-1-Barakat gave suitable refusals to the claims of so-called "Jahmis", one of the separated parties in religion. In tafsir of ayahs, commenting on the peculiarities of the paradise the author says: "Jahmis consider the paradise and its nhabitants temporary. However, Allah the Omnipotent stressed that those who admitted to the paradise will stay there forever". So the inhabitants of the paradise stay there forever and the paradise never disappear".

In the 25 th ayah of the "Baqara" Surah, Allah the Omniscient said: "Tell those faithful Muslims who remember the God and are engaged in good acts that they are guaranteed a place from the paradise with running streams under their seats".

Abu-l-Barakat provides this ayah as a proof against those who consider the good act as a component part of faith (belief) and says: "In this ayah the phrases "good act" and "faithful Muslims" are separated by a conjunction "va" (and). According to the grammatical rule of the Arabic language, the words and phrases separated by conjunctions are separate words and phrases. Therefore, the phrases good act" and "those faithful Muslims who remember the God" denote different things. However, one should not come to the conclusion that those Muslims who remember the God but do not perform good acts may be admitted to the paradise. The main claim to be admitted to the paradise is that man must act with a good will". Thus, Abu-l-Barakat supported the ideas expressed by the Maturidiya School.

Allah the Great says about the obedience to the leaders in the 5th ayah of the "Nisa" Surah: "Hey, faithful people! Obey Allah! Obey your Prophet and your leaders chosen from your company". Relying on this ayah, Abu-1-Barakat calls people to obey their leaders both in religious and secular affairs. He stresses that if a s faithful, he is usually obedient and would not support chaos.

Well-known expert in the science of tafsir Imam al-Bayzavi ils on this ayah in the same way as anNasafi treated it and that "a man who follows his leader should not betray him".

As is seen from the proofs of the two experts of tafsir, we can conclude that a man should always follow the ideas of his leader should not betray him both in religious and secular matter whether he is a ruler or the leader of the company he belongs to. Thus, an-Nasafi earned a great fame among the estimated scholar of his time. As is mentioned by Abdulhay al-Laknavi, "Abu-l. Barakat an-Nasafi was one of the greatest scholars of his time in the fields of law and style. He was famous also in the fields of Hadiths and tafsir. His commentaries were the highest of all" [3: 291]. A famous scholar al-Asqalani 


\begin{tabular}{|c|c|c|c|c|c|c|}
\hline \multirow{4}{*}{ Impact Factor: } & ISRA (India) & $=3.117$ & SIS (USA) & $=0.912$ & ICV (Poland) & $=6.630$ \\
\hline & ISI (Dubai, UAE & $=0.829$ & РИНЦ (Russia & $=0.156$ & PIF (India) & $=1.940$ \\
\hline & GIF (Australia) & $=0.564$ & ESJI (KZ) & $=8.716$ & IBI (India) & $=4.260$ \\
\hline & JIF & $=1.500$ & SJIF (Morocce & $=5.667$ & OAJI (USA) & $=0.350$ \\
\hline
\end{tabular}

mentions him with the honorable title "A Genius of the World".

\section{CONCLUSION}

As a conclusion of the above-mentioned facts, we may say that the scholars of ancient Nasaf made a tremendous contribution to the formation and further development of the religious and secular sciences, especially to the dissemination of the Hanafian order and teachings of the Maturidia School in the Islamic world and left a great amount of scientific heritage. From this point of view, studying and investigating the legacy of Abu-1-Hafs, Abu-1-Muin and Abu1-Barakat
an-Nasafi, and spreading them among the public and younger generation is of great importance. As has been stressed by our President, "The names of tens of world-famous geniuses coming from the city of Nasaf only and their creative activities under the penname of "an-Nasafi" are well known throughout the world. These scholars and estimated experts in different branches of science who made substantial contribution to the treasure of sciences with their scientific heritage and enriched the fame of our country throughout the world are the pride of not only Kashkadarya but also the whole Uzbek people".

\section{References:}

1. Muhammad Shafiq G'irbol (1995). Al-Mavsuat al-arabiya al-muyassara. V. II. Dor al-jayl va-1jamiya al-misriya li-nashr al-marifa va-s-saqofa al-alamiya.

2. Zaynuddin Qosim ibn Qutlubug'a (1996). Toj attarojim fi tabaqot al-hanafiya. Nendeln, Liechtenstein.

3. Abdulhay al-Laknaviy (1998). Al-Favoid albahiya fi tarojum al-hanafiya. Bayrut.

4. Muhammad Husayn az-Zahabiy (1995). AtTafsir va-l-mufassirun. V. II. - Qahira, I v.

5. (1892). Hoji Xalifa (Mulla Kotib ach-Chalabiy). Kashf az-zunun. V. II. Al-Alam, 1310/1892-3. II v.
6. Ahmad ibn Abu Said Siddiqiy (n.d.). Nur alAnvor fi sharh al-Manor / Nashir - Muhammad Abd al-Xoliq. Yusufiy matbaasi.

7. Abul Barakot Nasafiy va uning (2014). "Madorik at-tanzil va haqoiq at-ta'vil" asari" (monografiya). Tashkent: Movarounnahr.

8. Ahmad an-Naqib (2001). Al-Mazhab al-hanafiy. V. II. - Ar-Riyod: Maktabat ar-rushd, 2001. II v.

9. (n.d.). Qur'oni karim ma'nolarining tarjima va tafsiri / Tarjima va tafsir muallifi - A.Mansur. Tashkent: «Toshkent islom universiteti» nashriyot-matbaa birlashmasi.

10. Abul Barakot an-Nasafiy (1995). Tafsir anNasafiy al-musammo Madorik at-tanzil va haqoiq at-ta'vil. V. II. - Bayrut: Dor al-kutub alilmiya. 